\title{
Case Report: \\ ENDOVASCULAR STENTING IN PERIPHERAL ARTERIAL DISEASE OF LOWER EXTREMITY
}

\author{
Yudi Her Oktaviono \\ Department of Cardiology \\ Universitas Airlangga, Dr. Soetomo Hospital \\ Surabaya
}

\begin{abstract}
ABSTRAK
Penyakit arteri perifer (PAD) biasanya disebabkan oleh penyakit aterosklerosis bertingkat, biasanya pada pasien dengan riwayat merokok, diabetes mellitus, atau keduanya. Klaudikasio intermiten (IC), merupakan manifestasi awal dari PAD, umumnya menyebabkan penurunan kualitas hidup bagi pasien yang terbatas dalam ambulasi mereka. intervensi perkutan untuk penyakit arteri perifer telah berevolusi dari balon angioplasty untuk lesi fokal sederhana untuk teknik multimodality yang memungkinkan pengobatan insufisiensi arteri parah. Khusus untuk stenosis bermutu tinggi atau oklusi arteri pendek, perkutan angioplasti transluminal (PTA) harus menjadi metode pilihan pertama diikuti oleh prosedur bedah terbaik di kemudian hari. Untuk mencapai keberhasilan jangka panjang yang baik, dekat tindak lanjut termasuk tes objektif dari kedua lesi arteri dan status hemodinamik, pengawasan tindakan pencegahan sekunder dan kontrol faktor risiko adalah wajib. (FMI 2016;52:140-147)
\end{abstract}

Kata kunci: penyakit arteri perifer, klaudikasio intermiten, perkutan angioplasti transluminal

\begin{abstract}
Peripheral arterial disease (PAD) is usually caused by multilevel atherosclerotic disease, typically in patients with a history of cigarette smoking, diabetes mellitus, or both. Intermittent claudication (IC), an early manifestation of PAD, commonly leads to reduced quality of life for patients who are limited in their ambulation. Percutaneous intervention for peripheral artery disease has evolved from balloon angioplasty for simple focal lesions to multimodality techniques that enable treatment of severe arterial insufficiency. Especially for high-grade stenoses or short arterial occlusions, percutaneous transluminal angioplasty (PTA) should be the method of first choice followed by the best surgical procedure later on. To achieve good long-term efficacy, a close follow-up including objective tests of both the arterial lesion and hemodynamic status, surveillance of secondary preventive measures and risk factor control is mandatory. (FMI 2016;52:140-147)
\end{abstract}

Keywords: peripheral arterial disease, intermittent claudication, percutaneous transluminal angioplasty

Correspondence: Yudi Her Oktaviono, Departement of Cardiology Dr. Soetomo Hospital, Jl. Mayjen Prof. Dr. Mustopo 6-8, Surabaya, East Java, Indonesia. phone: 62-31-5501701.e-mail: yhoktaviono@yahoo.com

\section{INTRODUCTION}

AHA defines the PAD as a group of disorders that arise due to stenosis or occlusion or dilatation of the aorta aneurismatik progressive and branches of non-coronary artery, including branches of the carotid, upper extremity, lower extremity visceral and branches. PAD is a marker of systemic atherosclerotic. The prevalence is estimated to be around $12 \%$ of the adult population that is more found in women. PARTNERS study suggests nearly $29 \%$ revenue obtained at the age above 70 years or at the age of 50-69 years with a history of smoking more than 10 pack per year, or 50-69 years old with a history of diabetes mellitus. Although the prevalence is quite high, PAD is often undiagnosed because of atypical clinical presentation or even no complaints at all (Hirschet et al 2006, Mousa et al 2007).

In most cases, PAD showing the process of atherosclerosis in the arteries of the lower limb (lower extremity arterial disease/LEAD), of which nearly $30 \%$ gain lesions in the iliac arteries with clinical manifestations such as intermittent claudication (Mousa et al 2007, Tendera et al 2011).

The use of intervention as an option endovascular arterial occlusive lesion revascularization therapy is growing. Evolution in technology endovascular intervention showed improved developmental outcomes with this technology. In general, equally good results obtained in the two revascularization techniques in arterial occlusive disease, both with open surgical 
techniques as well as techniques transluminal angioplasty. Percutaneous angioplasty technique has the advantage, among other periprocedural morbidity and mortality is lower than open surgery. However, longterm patency as well as open surgical techniques. Although in some cases obtained late restenosis, this problem can be handled well with reintervensi without requiring open surgery (Hirschet et al 2006, Mousa et al 2007, Tendera et al 2011).

\section{CASE REPORT}

\section{Case I}

A man, Mr. BS, age 50, was referred from a heart clinic to undergo coronary angiography. Complaints of chest pain experienced since 6 months, especially when the activity being and complaints disappeared after the break. In addition, patients also complain of frequent cramps in the right leg when walking quite a distance, sometimes accompanied by a feeling tight in the hamstrings. Patients had a history of smoking at a young age. History of diabetes mellitus of the patient was since 5 years and patients-not regularly visit a doctor in the clinic to receive glibenclamide treatment and history of cholesterol.

Physical examination to get a general state of compost mentis, blood pressure $160 / 90 \mathrm{~mm} \mathrm{Hg}$, pulse $80 \mathrm{x} / \mathrm{min}$, breathing $16 \mathrm{x} / \mathrm{min}$ and a temperature of afebrile. Head and neck were within normal limits. Heart and abdomen were within normal limits. Upper and lower extremities within normal limits. ABI measurement showed a value of 0,83 in the extremities dekstra.

Laboratory tests showed $\mathrm{Hb} 14.3,6800$ leukocytes, platelets 230,000, HCT 41.7\%, LED $11 \mathrm{~mm}$ /hour, BUN $18.9 \mathrm{~g} / \mathrm{dl}$ serum creatinine $1.1 \mathrm{~g} / \mathrm{dl}$, fasting glucose 369 $\mathrm{g} / \mathrm{dl}$, sodium 140 , potassium 4.42 , and HBsAg positive. Total cholesterol $244 \mathrm{~g} / \mathrm{dl}$; triglycerides $186 \mathrm{~g} / \mathrm{dl}$; HDL $41 \mathrm{~g} / \mathrm{dl}$ and LDL $152 \mathrm{~g} / \mathrm{dl}$. ECG shows sinus rhythm 75 $\mathrm{x} / \mathrm{min}$, normal axis. Chest $\mathrm{x}$-ray showed within normal limits.

Echocardiography shows valve-valve: mitral regurgitation and tricuspid regurgitation trivial, chamber dimensions in the range of normal, normal LV systolic function ( $\mathrm{EF}$ 64\%); LV diastolic function abnormal relaxation. Normokinetik LV segmental analysis showed no LVH.

Patients diagnosed with coronary heart disease + stage 1 hypertension dyslipidemia JNC 7+++ Diabetes Mellitus intermittent claudication pro evaluation and therapy 1-0-
0 Noperten $5 \mathrm{mg}$, simvastatin $20 \mathrm{mg}$ 0-0-1, 1-1-0 gliclazide, Fasorbid 2x5 mg and 1×100 mg Aspilet

On January 30, 2011 coronary angiography performed by transfemoral access, but the wire stuck around dextral common iliac artery. Then arteriography in hand inject attempted. There is a suspicion of stenosis lesions in the abdominal aorta. The procedure is stopped and planned for coronary angiography and arteriography of the abdominal aorta in transradial.

On February 1, 2011 made by transradial coronary angiography. Results obtained: LMCA normal; LAD: 80\% stenosis in the proximal, $\mathrm{Cx}$ : long lesions with a maximum of $70 \%$ stenosis in the proximal and RCA: subtotal stenosis in the proximal-mid. Aobdominalis aortic arteriography performed, and the results obtained subtotal stenosis of the dextral common iliac artery TASC B. Patients planned to do PTCA for coronary lesions and endovascular procedures for iliac lesions.

On March 29, 2011 percutaneous angioplasty therapy for lesions in dextral common iliac. Therapy begins with the left common femoral artery puncture, do reevaluation, and decided to do angioplasty with retrograde technique of ipsilateral access through the dextral femoral artery. The action begins with wiring passing lesion stenosis with wire rood runner RPC 0.035260 retrograde past the lesion stenosis and successfully. Then predilataion was done with balloon Cook ATB advance $5 \mathrm{~mm} / 40 \mathrm{~mm}$ followed by the installation of expanded stent Optimed Superflex 535 $10 \mathrm{~mm} / 80 \mathrm{~mm}$ and continued with post-dilatation with a ballon Cook ATB advance $10 \mathrm{~mm} / 40 \mathrm{~mm}$, obtained outcome is good with residual stenosis $0 \%$. Patients receive additional therapy $1 \times 75 \mathrm{mg}$ clopidogrel. The clinical evaluation of the patient prior to KRS obtained no more complaints of intermittent claudication $\mathrm{ABI}$ score with 1:08 on the right inferior extremity (grade $+3)$.

\section{Case 2}

Mr AY, a male, age 73 years with complaints often feels pain in the right leg when walking some distance away. Patients had a history of smoking for a long time. Patients showing a history of diabetes mellitus since 8 years, dyslipidemia and hypertension, and a history of coronary heart disease and stenting was performed in February 2010 and September 2011, and also got artery occlusion in dextral common iliac $1 \times 75 \mathrm{mg}$ with Plavix therapy, Lipitor $40 \mathrm{mg}$ 0-0-1, amlodipine 5mg-0-0, ISDN $2 \times 5 \mathrm{mg}$, Lantus injection 10U 0-0-1. 


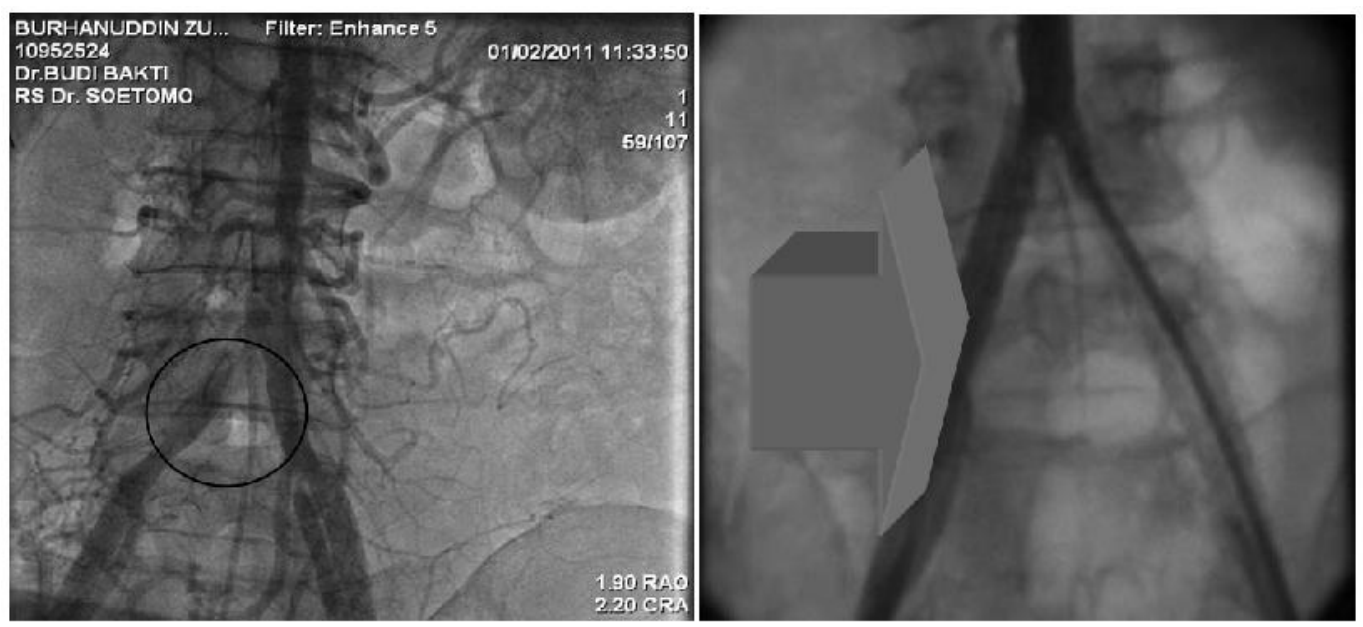

Figure 1. X-Ray photo of the Case I

Physical examination dated March 29, 2011 shows the general state of compost mentis, blood pressure of $140 / 80 \mathrm{~mm} \mathrm{Hg}$, pulse $75 \mathrm{x} / \mathrm{min}$, breathing $20 \mathrm{x} / \mathrm{min}$ and a temperature of afebrile. Head and neck within normal limits. Heart and abdomen within normal limits. Upper and lower extremities within normal limits. ABI measurement showed a value of 0.75 in dextral extremities.

Laboratory tests showed $\mathrm{Hb} 13.7,6510$ leukocytes, platelets 188,000, HCT 41.7\%, LED $11 \mathrm{~mm}$ /hour, BUN $25 \mathrm{~g} / \mathrm{dl}$ serum creatinine $1.6 \mathrm{~g} / \mathrm{dl}$, fasting glucose $85 \mathrm{~g} / \mathrm{dl}$, sodium 139, potassium 4.2, and $\mathrm{HBsAg}$ negative. SGOT/SGPT 21/38. ECG shows sinus rhythm $75 \mathrm{x} / \mathrm{min}$, normal axis. Chest $\mathrm{x}$-ray was within normal limits.

Echocardiography shows valve-valve: no visible abnormalities, chamber dimensions in the range of normal, normal LV systolic function (EF 64\%); abnormal diastolic function LV relaxation, LV segmental analysis normokinetik, not found LVH. Patients diagnosed with coronary heart disease diabetes mellitus post PCI ++ dextral common iliac artery occlusion.

On October 3, 2011 to be evaluated for lesions in the dextral common iliac artery arteriography with access via the left femoral artery. Outcome showed long lesions with a maximum of subtotal stenosis at the proximal and distal right common iliac artery TASC B. The approval of the patient and family, percutaneous angioplasty is done, starting with the right femoral artery puncture (ipsilateral), tried to do wiring lesion stenosis with wire Terumo 0.02520 retrograde past the lesion stenosis and successfully. Then, the balloon Cook ATB predilatation with advance $7 \mathrm{~mm} / 40 \mathrm{~mm}$ from the proximal to the distal proceed with the installation of expanded stent Sinus Superflex $5358 \mathrm{~mm} / 80 \mathrm{~mm}$ and continued with post-dilatation with a ballon Cook ATB advance $10 \mathrm{~mm} / 40 \mathrm{~mm}$. Outcome is good with $0 \%$ residual stenosis. The clinical evaluation of patients before hospital discharge showed complaints of intermittent claudication was reduced by ABI score 1 . 05 on the right inferior extremity (Grade +3$)$.

\section{DISCUSSION}

Epidemiology of LEAD was reported from several studies in various European countries. Population study in Sweden in the population aged 60-90 years showed LEAD prevalence of $18 \%$, while those suffering from intermittent claudication were $7 \%$. Nearly a third of people have complaints typical LEAD. The prevalence of CLI is much smaller at around $0.4 \%$. It is generally estimated incidence of CLI every year approximately 500-1000 new cases per 1 million population with the highest incidence was found in patients with diabetes mellitus. Framingham study states claudicasio intermittent incident in males approximately 0.4 per 1000 persons in the population aged 35-45 years and rose above 6 per 1000 people at the age above 65 years. The incidence in women about half than the incidence in males in the same age population. Amputation do around 120-500 per 1 million people per year. This trend has increased so that the epidemiology of LEAD are difficult to predict due to changes in the atherosclerotic risk factors that are difficult to control, such as smoking and diabetes mellitus. (Hirschet et al 2006, Tendera et al 2011, Brunner \& Caralis 2005, Mahmud et al 2007). 

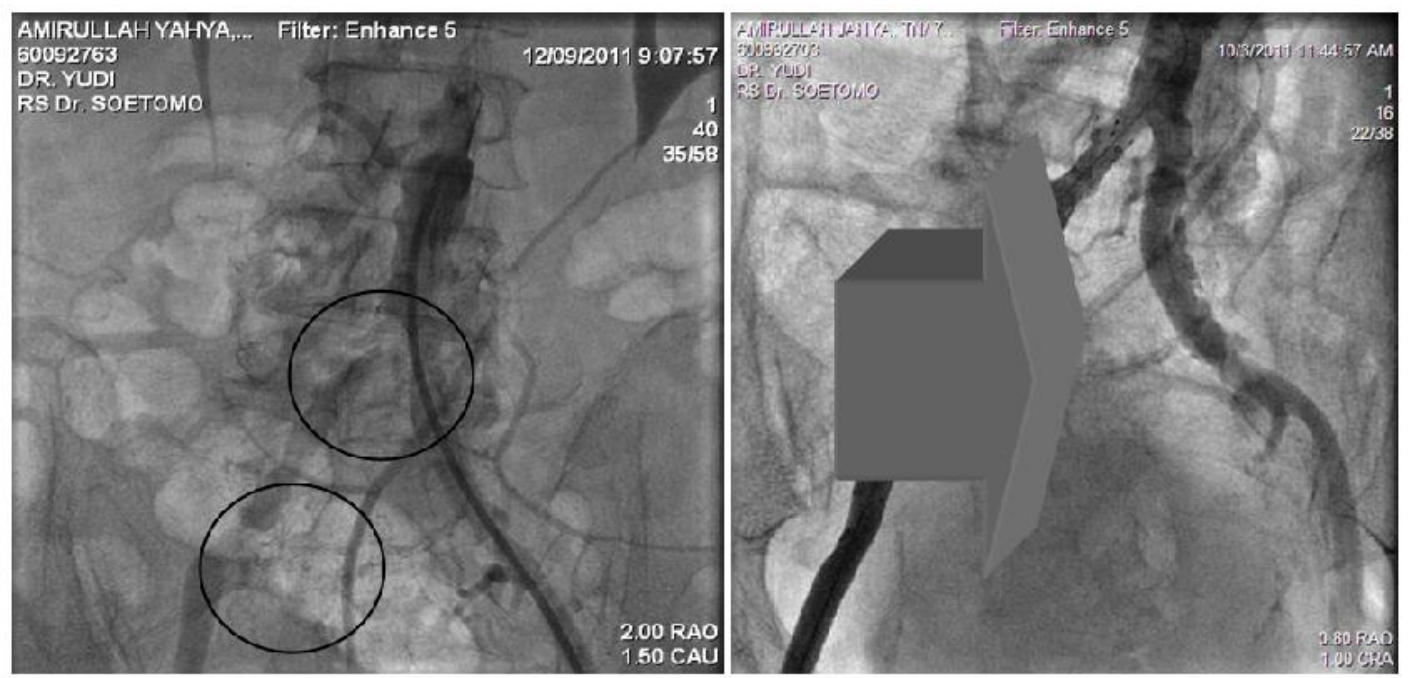

Figure 2. X-Ray photo of the Case II

Most of the cases of asymptomatic LEAD. Diagnosis is made on clinical examination showed a decrease in peripheral arterial pulses or even pulses or from $\mathrm{ABI}$ score. In the symptomatic LEAD obtained in the form of typical clinical picture of intermittent claudication are pain in the thigh increased when walking and disappears quickly at rest (Fontaine st II; Rutherford grade I). In some cases with a more proximal lesions (aortoilliac), obtained complaints of pain in the buttocks and thigh area. Complaints of pain must be distinguished from complaints due to venous disease (complaint on the break, rising late in the afternoon and often disappears with rest) arthritis of the knee and hip (pain when walking that does not disappear with rest) and peripheral neuropathy (reduced pain when walking, but does not improve with rest) (Hirschet et al 2006, Tendera et al 2011, Brunner \& Caralis 2005, Mahmud et al 2007, Liapis \& Tzortzis 2004).

Several noninvasive examination helpful in diagnosis LEAD, among others ABI score, duplex ultrasound, ultrasound CW Doppler and pulse volume recording. $\mathrm{ABI}$ is an easy and inexpensive examination in the diagnosis of PAD, but had a sensitivity, specificity approaching the gold standard diagnostic for PAD, ie angiography, so this investigation into the initial screening is recommended in patients with suspicion of PAD. ABI value $<0.90$ is an indicator of the presence of significant stenosis lesion (Hirschet et al 2006, Tendera et al 2011, Mahmud et al 2007, Liapis \& Tzortzis 2004).

Based on the characteristics of the structure and anatomy, lower extremity arterial system can be divided into three segments, namely: aorto-iliac, femoropopliteal and infrapopliteal arteries. Aortoilliac lesions distinguished by its location, morphology (stenosis vs occlusion), and expansion. TASC ortoilliac classify lesions into four classes: (1) TASC type A: single lesions $<3 \mathrm{~cm}$ in CIA or EIA (bilateral/unilateral), (2) the TASC type B: a) Single stenosis $3-10 \mathrm{~cm}$ in length, not extending into the common femoral artery (CFA), b) Total of 2 stenoses $<5 \mathrm{~cm}$ long in the CIA and/or EIA and not extending into the CFA, c) Unilateral CIA occlusion; (3) TASC type C: a) Bilateral 5-10-cm-long stenosis of the CIA and/or EIA, not extending into the CFA, b) Unilateral EIA occlusion not extending into the CFA, c) Unilateral EIA stenosis extending into the CFA, d) Bilateral CIA occlusion. (4) TASC type D: a) Diffuse, multiple unilateral stenoses involving the CIA, EIA, and CFA (usually $>10 \mathrm{~cm}$ ), b) Unilateral occlusion involving both the CIA and EIA, c) Bilateral EIA occlusions, d) Diffuse disease involving the aorta and both iliac arteries, e) iliac stenoses in a patient with an abdominal aortic aneurysm or other aortic or iliac lesions requiring surgery (Mousa et al 2007, Liapis \& Tzortzis 2004, Creager et al 2008).

In both the above cases obtained clinical Fontane 2a clinical LEAD with Rutherford grade I. ABI values obtained from the examination $<0.90$ with mildmoderate PAD suspicion. Results arteriography in case I showed the existence of subtotal stenosis in arterial lesions dextra common iliac with TASC classification of type B and cases II obtained long with a maximum stenosis $80 \%$ lesion in the proximal and distal dextral common iliac arteries with TASC classification of type B.

Several therapeutic strategies that can be selected in the LEAD management include: (1) conservative therapy, 
among others, exercise therapy and pharmacotherapy. Exercise therapy aims to improve symptoms and increase exercise capacity. Pharmacological therapies that can be administered to patients with LEAD including: class of lipid-lowering, antihypertensive drugs, class of antiplatelet and antithrombotic and class of phosphodiesterase inhibitors, such as pentoxifilin and PDE-3 inhibitor is cilostasol and therapeutic invasive with endovascular surgery (Mousa et al 2007, Brunner \& Caralis 2005, Liapis \& Tzortzis 2004).

\section{Revascularization strategy: percutaneous angioplasty versus surgery}

Surgical treatment options aorto-iliac lesions currently include aortobifemoral bypass surgery, endarterectomy and ILLIAC aorto-femoral-femoral bypass. Endovaskular therapy for lesions aortoiliiac include PTA or PTA + stenting. Aortobifemoral bypass surgery is still the gold standard for the selection of aorto-ILLIAC lesion revascularization (Tendera et al 2011, Brunner \& Caralis 2005, Liapis \& Tzortzis 2004).

The objective of endovascular stenting is (1) improve the conditions of primary insufficiency such as residual stenosis, extensive recoil flow, minimizes the risk of dissection and (ii) improve the long-term patency. Generally stenting avoided at the location of "bending" as the hip and knee joints, and the segment that is suitable for landing zone when the predicted action will be required bypass surgery (Tendera et al 2011, Almahameed \& Bhatt 2006, Brunner \& Caralis 2005).

Excellence action endovascular on LEAD (1) reduce or eliminate complaints ischemia of the lower limb including claudication, rest pain and ulcers or gangrene (ii) improve blood flow to the lower extremities when needed action bypass section of the distal (iii) provide vascular access to the proximal part of the especially when the lesion will do more invasive procedures such as cardiac catheterization/PTCA and installation of IABP (Mousa et al 2007, Tendera et al 2011, Liapis \& Tzortzis 2004).

Endovascular bypass surgery offers faster recovery, requires shorter hospital stay, requires no general anesthesia, maintains all options for extremity revascularization, allows for the preservation of the saphenous vein for the future use (CABG), may be repeated if necessary, may be combined with surgery to improve the inflow or outflow of surgical grafts placed, Considered the gold standard, has good long-term patency, and may be preferable to treat multiple conduit venous stenosis if available. However, the disadvantages are lower primary patency rate, reinterventions due to restenosis, limited used in presence of multiple level stenosis, cost benefit ratio for severe advanced PVD is debatable, higher rate of morbidity, potential systemic complication, typically requires general anesthesia, requires harvesting of saphenous veins and upper extremity veins, and precluding Reviews their use for $\mathrm{CABG}$.

Selection of determining suitable candidates for revascularization therapy is determined case by case under the supervision of specialist endovascular and vascular surgery. Some things are a major consideration is the selection of therapeutic strategy anatomical suitability, comorbid conditions in patients, the ability and experience of the operator and also the preference of the patient's own (Caulfield et al 2005, Dimitrios \& Raman 2008).

Several factors are predicted to affect the patency of action PTA include: (1) the nature and severity of lesions (2) the anatomy of the affected limb (3) clinical manifestations of the extremities due to lesions (4) the response angiography to the intervention (4) physiological responses of lesions of interventions (5) systemic factors such as diabetes mellitus, smoking, hypertension and hypercholesterolemia.

While the lesions are diffuse, small blood vessels, diabetes mellitus, women, critical limb ischemic, poor runoff and total occlusion provide a low patency. Several multivariate analysis states that the lesion stent patency rate at CIA lower when compared to the EIA (MacNeill \& Rosenfield 2005, Singh 2003).

Some conditions that contraindicate relative endovascular actions include: total occlusion, lesion length, atheroemboli, aorto iliac aneurysms, athero-embolic disease and the extensive bilateral lesions (Caulfield et al 2005).

The actions of the PTA procedure is generally very similar to the PTCA procedures, including loading Aspirin $(325 \mathrm{mg}$ ) was given a few days before the procedure and after the action of vascular access is obtained, prior to the intervention regularly, given heparin 2500-5000 units (Mahmud et al 2007, MacNeill \& Rosenfield 2005, Gianluca \& Paolo 2012).

At the lesion revascularization in the aorto-ILLIAC segment, the approach may be required by one or more arterial access. Determination of access route will be chosen to be very important for the smooth action angioplasty and minimize the risk of complications. Various considerations in determining access options are: palpability of access arterial, the possibility of access into the arterial, predicted severity of the lesion if it is possible to reach from access arterial, avalibility of 
equipment used (wire, sheaths, balloon or stent), and the possible use of thrombolytic agents and projections angiography.

Some of the considerations in determining the choice of location of access and PTA techniques: (1) on the side ipsilateral retrograde approach through the common femoral artery access is an option on iliac lesion, unless obtained illiac artery lesions were located very distal and there is no lesions in the femoral artery area. Another advantage is that it can provide a "landing zone" and adequate support to the sheath. In the near the bifurcation lesions, this technique is extremely accurate positioning of the balloon or stent. (2) The approach antegrade recommended when (i) the target lesion located close to the common femoral artery or the base of the femoral artery, (ii) vascular distal lesions obtained scar or condition of common femoral artery highly calcified (iii) if the estimated position of a sheath would affect or hinder the process of revascularization and (iv) if the distal lesion revascularization performed, expected in inline position as the angulated lesions in the aortic bifurcation. (3) The approach of the brachial artery on the right and left considered severe bifurcation lesions, long lesions iliac occlusive indispensable where the coaxial wire manipulation. This approach should be avoided if planned for thrombolytic procedure. (4) On election occlusive lesions of the ipsilateral and contralateral access equally well depend on the high level of ostium lesions of common iliac and the inlet area in the femoral artery. Generally, the technique of simultaneous pair may break segment occlusion or lesions occlusive sometimes need access through the popliteal artery or approach to access brachial because it allows for the manipulation wire to the maximum (Mahmud et al 2007, Liapis \& Tzortzis 2004, Mahmud et al 2007, Singh 2003, Gianluca \& Paolo 2012).

Selection of wire considered on several things, including nature of the lesion stenosis or occlusion, blood vessel diameter, turtoisity and compatibility of other tools. In general, the large blood vessel wire 0.035 "- 0.038 " is quite compatible, while the blood vessels are small wire $0.014 "$ or $0.018 "$ is quite compatible. In occlusion lesion is advisable to use wire with a sharp tip that makes it easy for crossing lesions and hydrophilic (Mahmud et al 2007, Singh 2003, Gianluca \& Paolo 2012).

Selection of the balloon should be adjusted to the recommended diameter segment. If the diameter of blood vessels is not known, it can be used intravascular ultrasound help to ensure the vessel lumen diameter. If not available IVUS underdilatation then performed on the lesion to avoid the risk of rupture. Ballon material is compliant or semicompliant provide benefits for oversizing compared with non-compliant balloon or high pressure ballon with more minimal risk of rupture (Mahmud et al 2007, Singh 2003, Gianluca \& Paolo 2012).

The use of an angioplasty stent as adjuvant therapy aims to enlarge the diameter of the lumen and provide support to the vascular lumen and decrease the incidence of complications and restenosis. Currently there are two types of stents for peripheral vascular angioplasty adjuvant that is balloon expandable stent (stent BE) and a self-expanding stent (SE stent). BE stents have a higher accuracy in the placement in the lesion area and have a high radial strength than the SE stent. BE generally more resistant to the risk of deformity after developed. While SE stent is known by the nature of the higher flexibility (Heuser \& Henry 2008).

Besides preferable depending on the operator, the selection of the type of stent also considered several factors, including morphology and location of the lesion. In lesions with high elastic recoil, such as calcified lesions or eccentrique plaques in the ostium of the CIA or EIA, BE stent is more advisable than the SE stent because it has a larger hoop strength. SE stent can have on the type of lesion length, which is less calcified lesions. Turtous lesions, the use of SE stent is not recommended, because of the risk of angulation and kinking of blood vessels in the distal stent. SE stent (nitinol, wallstent) should be used because of the nature of good flexibility and corformability on the vessel when developed. Nitinol stent is also highly suited to the lesions, which are located in transition area, which found a difference helping the blood vessel lumen diameter significantly (from CIA to EIA difference lumen diameter $>2 \mathrm{~mm}$ ). In lesions osteal and nonosteal iliac lesion, BE stent is generally a recommended option, since stent placement easier with fairly good accuracy, and has a radial strength is good and radiovisibility better than SE (Mahmud et al 2007, Liapis \& Tzortzis 2004, Mahmud et al 2007, Singh 2003, Gianluca \& Paolo 2012).

Several studies since 1990 meta-analysis, which compares the results of balloon angioplasty with stenting in iliac stenosis, showing long-term risk of failure is lower in stenting compared to balloon angioplasty, with patency within 3 years post procedure about $80-90 \%$, almost the same as the patency of action revascularization surgery were approximately $91 \%$ in $88 \%$ of cases of claudication and CLI (Almahameed \& Bhatt 2006, Mahmud et al 2007, MacNeill \& Rosenfield 2005, Singh 2003). 
In 1993 the FDA approved the use of Palmaz balloon expendable stent to the lesion in arteries illiaca, which is indicated in cases of PTA failure (mean residual gradient of $5 \%$, residual stenosis $>30 \%$ or obtained dissection). In 1996 the self-expanding wall stent approved for the same indication. But the latest research results show that the hemodynamic and angiographic outcomes, post stenting minimal recoil effect, better than angioplasty. Therefore the indication of the use of stents in the iliac stenosis becomes more widespread (Singh 2003, Caulfield et al 2005).

The study meta-analysis by Bosch et al states from 2100 patients who underwent PTA in the area aortoiliac, outcomes use of stents are superior to balloon angioplasty alone with immediate success rate (96 vs $91 \%$ ) with a 4-year patency rate of the lesion stenosis 77 vs $65 \%$ and Reviewed occlusion lesions 61 vs $54 \%$ (Caulfield et al 2005)

Schurmann et al reported a patency rate of use of selfexpanding nitinol stent of 110 patients were followed up within 5 years of approximately $83 \%$ (Heuser \& Henry 2008). AHA provides guidelines for the evaluation of the results of percutaneous angioplasty for peripheral arterial lesions as follows:

In case I do PTA retrograde of ipsilateral lesion side, starting with the wiring and predilatation with balloons, followed the installation of expanded stent with good outcome, residual stenosis $0 \%$. In the case of retrograde PTA II carried on the side ipsilateral to begin wiring passes stenosis and predilatation with ballon ranging from proximal to distal and proceed with the installation of the expanded stent with good outcome, residual stenosis $0 \%$. Clinical data showed improvement and the evaluation of endovascular post ABI score showed grade +3 .

Some of the complications that can occur in an angioplasty lesions in the aorto-iliac although the frequency is very rare that less than $6 \%$, of which: (i) localized bleeding at the puncture area (5-18\%) or retroperiteal, pseudoaneurysm, atrioventricular (AV) fistula (ii) occlusive thrombus on the side that performed angioplasty (iii) arterial rupture which can generally be overcome with the development of balloon rupture in the area, accompanied by a reversal of the anticoagulant effect and volume resuscitation and implantation of the stent graft (v) distal embolization. Systemic complications that can occur include: (i) renal dysfunction as a result of the use of contrast agents or thrombus embolism (ii) myocardial infarction (iii) CVA (iv) mortality and the incidence is less than $0.5 \%$. The emergence of complications requiring surgical treatment is also very rare, ie less than $2 \%$ (Liapis \& Tzortzis 2004, Gianluca \& Paolo 2012, Caulfield et al 2005).

\section{CONCLUSION}

It has been reported 2 cases of patients with the disease occlusive lower extremity with clinically Fontan 2 rutherfords 1 with the results of angiography subtotal common iliac stenosis TASC B in the first case and long lesions in common iliac artery with a maximum stenosis of $80 \%$ in the proximal and distal TASC B action angioplasty with the installation of self expended percutaneous stent with good results to be obtained from the clinical improvement and ABI score.

\section{REFERENCES}

Almahameed A and Bhatt DL (2006). Contemporary management of peripheral arterial disease: III. Endovascular and surgical management. Cleveland Clinic Journal of Medicine 73, S45-51

Brunner MC and Caralis DG (2005). Endovascular strategies for management of claudication and lower extremity arterial disease. In: Caralis DG and Bakris GL (eds). Lower Extremity Arterial Disease, New Jersey, Humana Press Inc, p 257-268

Caulfield MT, Fernando D, Rosenfield K (2005). Renal and iliac intervention. In: Herrmann HC (ed). Interventional Cardiology: Percutaneous Noncoronary Intervention, New Jersey, Humana Press Inc, p 295320

Creager MA, White CJ, Hiatt WR, Criqui MH, Josephs SC, Alberts MJ, Pearce WH, Gray BH, Rocha-Singh $\mathrm{KJ}$ (2008). Atherosclerotic peripheral vascular disease symposium II. Circulation 118, 2811-2825

Gianluca R and Paolo C (2012). Iliac artery stenosis. In: Nguyen TN, Hu D, Chen SL, Kim MH, Saito S, Grines CL, Gibson CM, Bailey SR (eds). Practical Handbook of Advanced Interventional Cardiology: Tips and Tricks, 3rd ed, New Jersey, John Wiley \& Sons Ltd, p 421-438

Heuser RR and Henry M (2008). Textbook of Peripheral Vascular Interventions, 2nd ed, London, Informa Healthcare

Hirsch AT, Haskal ZJ, Hertzer NR, Bakal CW, Creager MA, Halperin JL, Hiratzka LF, Murphy WR, Olin JW, Puschett JB, Rosenfield KA (2006). ACC/AHA 2005 practice guidelines for the management of patients with peripheral arterial disease (lower extremity, renal, mesenteric, and abdominal aortic). Circulation 113, e463-e654

Liapis CD and Tzortzis EA (2004). Advances in the management of iliac artery occlusive disease: a short 
review. Vascular and Endovascular Surgery 38, 541545

MacNeill BD and Rosenfield (2005). Peripheral intervention. In: Baim DS (ed). Grossman's Cardiac Catheterization, Angiography, and Intervention, 7th ed, Philadelphia, Lippincott Williams \& Wilkins, $p$ $562-603$

Mahmud E, Cavendish J, Salami A (2007). Current treatment of peripheral arterial disease: role of percutaneous interventional therapies. Journal of the American College of Cardiology 50, 473-490

Mahmud E, Cavendish JJ, Salami A (2007). Current treatment of peripheral arterial disease: role of percutaneous interventional therapies. J Am Coll Cardiol 50, 473-490

Mousa AY, Beauford RB, Flores L, Faries PL, Patel P, Fogler R (2007). Endovascular treatment of iliac occlusive disease: review and update. Vascular 15, 511
Nguyen LL (2007). Percutaneous treatment of peripheral vascular disease: the role of diabetes and inflammation. J Vasc Surg 45, A149-A157

Singh K (2003). Percutaneous ilio-femoral revascularizations. In: Nguyen $\mathrm{TN}, \mathrm{Hu} \mathrm{D}$, Saito $\mathrm{S}$, Grines CL, Palacios I (eds). Practical Handbook of Advanced Interventional Cardiology, 2nd ed, New Jersey, John Wiley \& Sons Ltd, p 427-429

Tendera M, Aboyans V, Bartelink ML, Baumgartner I, Clément D, Collet JP, Cremonesi A, DeCarlo M, Erbel R, Fowkes FGR, Heras M (2011). ESC guidelines on the diagnosis and treatment of peripheral artery diseases. European Heart Journal 32, 2851-2906

Tsetis D and Uberoi R (2008).Quality improvement guidelines for endovascular treatment of iliac artery occlusive disease. Cardiovasc Intervent Radiol 31, 238-245 